\title{
EFEKTIFITAS MODEL PEMBELAJARAN RESOURCE BASED LEARNING TERHADAP HASIL BELAJAR MATEMATIKA SISWA
}

\author{
Putri Yulia $^{1^{*}}$, Diana Natalia $^{2}$ \\ ${ }^{1}$ IAIN Kerinci \\ ${ }^{2}$ Universitas Riau Kepulauan \\ *putriyuliamz@gmail.com
}

\begin{abstract}
The background of this research is the problems faced by mathematics teachers where students are still less active in participating in the mathematics learning process and student learning outcomes are still low and have not yet reached KKM. The purpose of this study was to determine the effectiveness of the Learning Model Resource Based Learning and Conventional learning in terms of mathematics learning outcomes of students of class VIII MTs Al Muttaqin Batam. The type of research used is experimental research. The population of this study were all students of class VIII MTs Al Muttaqin Batam, amounting to 42 people. The sampling technique used was of the saturated sample type. it was concluded that there was a significant difference in the learning model of Resource Based Learning with conventional learning in terms of mathematics learning outcomes for students of class VIII at MTs Al Muttaqin Batam.
\end{abstract}

Key Words: Resource Based Learning; Learning Outcomes; Mathematics.

\begin{abstract}
Abstrak: Latar belakang penelitian ini adalah pemasalahan yang dihadapi oleh guru matematika dimana siswa masih kurang aktif dalam mengikuti proses pembelajaran matematika dan hasil belajar siswa yang masih rendah dan belum mencapai KKM. Tujuan penelitian ini untuk mengetahui keefektifan model pembelajaran Resource Based Learning dan pembelajaran Konvensional ditinjau dari hasil belajar matematika siswa kelas VIII MTs Al Muttaqin Batam. Jenis penelitian yang digunakan adalah penelitian eksperimen. Populasi dari penelitian ini adalah seluruh siswa kelas VIII MTs Al Muttaqin Batam yang berjumlah 42 orang. Teknik sampling yang digunakan berjenis sampel jenuh. disimpulkan bahwa terdapat perbedaan yang signifikan terhadap model pembelajaran Resource Based Learning dengan pembelajaran konvensional ditinjau dari hasil belajar matematika pada siswa kelas VIII di MTs Al Muttaqin Batam.
\end{abstract}

Kata Kunci: Resource Based Learning; Hasil Belajar; Matematika.

\section{PENDAHULUAN}

Guru dan lingkungan pendidikan merupakan wadah utama dalam mewujudkan tujuan dari pendidikan nasional sebagaimana tertuang dalam Undang-undang sistem Pendidikan Nasional RI No. 20 Tahun 2003 dalam pasal 3 dinyatakan bahwa Pendidikan
Nasional berfungsi mengembangkan kemampuan dan membentuk watak serta peradaban bangsa yang bermartabat, bertujuan untuk berkembangnya potensi peserta didik agar menjadi manusia yang beriman dan bertaqwa kepada Tuhan Yang Maha Esa, berakhlak mulia, sehat, 
berilmu, sehat, kreatif, mandiri, dan menjadi warga negara yang demokratis serta bertanggung jawab.

\section{Pembelajaran}

matematika

seharusnya diarahkan kepada kegiatankegiatan yang dapat memotivasi siswa untuk memahami matematika, karena kegiatan pembelajaran dikelas bertujuan untuk membantu siswa aktif membangun pengetahuannya (Yulia: 2016). Pengetahuan dibangun bila siswa aktif dan terlibat dalam kegiatan pembelajaran, bertanya secara aktif, dan mengelola bahan secara kritis sehingga dapat menguasai materi pelajaran dengan baik (Bagindo, Yulia: 2019). Tekanan dalam kegiatan pembelajaran adalah keterlibatan yang aktif dari siswa, keterlibatan aktif siswa dalam kegiatan untuk mengelola bahan, mengerjakan soal, membuat kesimpulan dan merumuskan sesuatu dengan kata-katanya sendiri adalah hal yang paling efektif guna membantu siswa membangun pengetahuan (Dewi, Yulia: 2018).

Berdasarkan hasil observasi awal yang telah di lakukan oleh penulis di MTs Al Muttaqin, tentang nilai hasil ujian matematika menunjukkan hasil belajar yang rendah. Siswa hanya bisa mengandalkan LKS dan guru sebagai sumber informasi di dalam proses belajar dan pembelajaran di sekolah. Sebagian besar siswa tingkat pemahamannya masih sangat kurang dikarenakan malas untuk membaca dan mencari sumber referensi.

Mengantisipasi permasalahan tersebut maka perlu diberikan formula pembelajaran yang tepat, sehingga dapat meningkatkan keaktifan siswa dalam pembelajaran matematika. Salah satu model pembelajaran yang menurut peneliti dapat membantu, memotivasi siswa untuk berperan aktif dalam proses belajar mengajar terutama untuk mampu mencapai tujuan pembelajran matematika adalah dengan menerapkan model pembeajaran Resource Based Learning. Model pembelajaran Resource Based Learning merupakan salah satu model pembelajaran yang menggunakan berbagai sumber belajar. Resource Based Learning adalah segala bentuk belajar yang menghadapkan murid dengan suatu atau sejumlah sumber belajar secara individual atau kelompok dengan segala kegiatan belajar yang bertalian dengan itu, jadi bukan dengan cara konvensional dimana guru menyampaikan bahan pelajaran kepada murid (Aliyah, Suyitno dan Agoestanto : 2014)

Berdasarkan latar belakang yang telah dijelaskan, maka penelitian ini bertujuan untuk mengetahui efektivitas model pembelajaran Resource Based Learning ditinjau dari hasil belajar matematika siswa kelas VIII di MTs Al Muttaqin Batam.

\section{TINJAUAN TEORETIS}

Dorrell dalam Siregar (2009) menuliskan bahwa istilah belajar beraneka sumber terkait dengan istilah lainnya, "resource-based learning is a broad heading used to cover open learning, distance learning and flexible learning, in which the use learning resources is the main thrust of any scheme developed". Menurut Dorrell, penggunaan berbagai sumber belajarlah yang merupakan sebagai pendorong 
dikembangkannya sistem belajar terbuka, belajar jarak jauh dan belajar fleksibel, sehingga istilah belajar berbasis aneka sumber sebenarnya sudah tercakup di dalamnya.

Menurut Nasution (2003: 19) Belajar berdasarkan sumber atau resource based learning bukan sesuatu yang berdiri sendiri, melainkan bertalian dengan sejumlah perubahanperubahan yang mempengaruhi pembinaan kurikulum. Perubahanperubahan itu mengenai perubahan dalam (1) sifat dan pola ilmu pengetahuan manusia; (2) masyarakat dan tafsiran kita tentang tuntutannya; (3) tentang pengertian kita tentang anak dan caranya belajar; (4) media komunikasi.

Menurut pendapat para ahli dalam Siregar (2009) pembelajaran melalui metode resource based learning (beraneka sumber) memberikan berbagai keuntungan antara lain:

1) Selama pengumpulan informasi terjadi kegiatan berpikir yang kemudian akan menimbulkan pemahaman yang mendalam dalam belajar (McFarlane, 1992)

2) Mendorong terjadinya pemusatan perhatian terhadap topik sehingga membuat peserta didik menggali lebih banyak informasi dan menghasilkan hasil belajar yang lebih bermutu (Kulthan, 1993)

3) Meningkatkan ketrampilan berpikir seperti ketrampilan memecahkan masalah, memberikan pertimbangan-pertimbangan dan melakukan evaluasi melalui penggunaan informasi dan penelitian secara mandiri (Todd \& Inc Nicholas, 1995)

4) Meningkatkan perolehan ketrampilan pemrosesan informasi secara efektif, dengan mengatahui sifat dasar informasi dan keberagamannya (Cleaver, 1986)

5) Memungkinkan pengumpulan informasi sebagai proses yang berkesinambungan sehingga mengakibatkan terbentuknya pengetahuan pada tiap fase berikutnya (Moore, 1995)

6) Meningkatkan sikap murid dan guru terhadap materi pembelajaran dan prestasi akademik (Cuel, 1991)

7) Membuat orang antusias belajar dan terinspirasi untuk berpartisipasi aktif (Wilbert, 1976)

8) Meningkatkan prestasi akademik dalam penguasaan materi, sikap dan berpikir kritis (Barrilant, 1965).

\section{METODOLOGI PENELITIAN}

Jenis penelitian yang digunakan adalah jenis penelitian eksperimen. Menurut Suharsimi (2006) Eksperimen adalah suatu cara untuk mencari hubungan sebab akibat (hubungan kausal) antara dua faktor yang sengaja ditimbulkan oleh peneliti dengan mengeliminasi atau mengurangi atau menyisihkan faktor-faktor lain yang mengganggu. Penelitian dengan melakukan sebuah studi objektif, sistematis, dan terkontrol untuk memprediksi atau mengontrol fenomena.

Rancangan penelitian ini menggunakan jenis penelitian kuasi eksperimen (quasi-experimental research). Hasil yang diperoleh dari 
perlakuan dapat diketahui secara pasti karena dibandingkan dengan yang tidak dapat perlakuan. Populasi dalam penelitian ini yaitu seluruh siswa kelas VIII MTs Al Muttaqin Batam dengan jumlah 42 siswa, sedangkan sampel pada penelitian ini adalah seluruh siswa kelas VIII MTs Al Muttaqin Batam yang berjumlah 42 siswa. Sesuai dengan metode yang digunakan, maka yang dibutuhkan pada penelitian ini hanya dua kelas yaitu kelas experimen dan kelas kontrol.

Variabel bebas dalam penelitian ini adalah perlakuan yang di berikan kepada siswa kelompok eksperimen yaitu pembelajaran dengan model pembelajaran Resource Based Learning, sedangkan variabel terikat dalam penelitian ini adalah gejala yang timbul akibat perlakuan yang diberikan oleh variabel bebas. Variabel terikat dalam penelitian ini adalah hasil belajar siswa kelas VIII di MTs Al Muttaqin Batam.

Instrumen penelitian adalah suatu alat yang dapat digunakan untuk memperoleh, mengolah dan menginterpretasikan informasi yang diperoleh dari para responden yang dilakukan dengan menggunakan pola ukur yang sama (Arikuntto: 2012). Instrumen yang digunakan adalah tes berbentuk uraian. Tes digunakan untuk mengukur hasil belajar matematika. Tes ini terdiri atas 10 butir soal. Sebelum tes diberikan kepada sampel penelitian, tes terlebih dahulu diuji coba pada kelas diluar kelas sampel yaitu kelas IX. Teknik analisis data dalam pengujian hipotesis menggunakan uji $t$ satu pihak. Pengujian digunakan untuk mengetahui apakah hipotesis diterima atau ditolak.

\section{HASIL DAN PEMBAHASAN}

Dalam hasil perhitungan uji normalitas untuk kelas kontrol diperoleh $\boldsymbol{\chi}^{2}$ hitung $=4,07$. Selanjutnya dibandingkan dengan harga $\chi_{\text {tabel }}^{2}$ dengan $\mathrm{dk}$ (derajat kebebasan) 7-1= 6 dan taraf signifikan $=5 \%$ maka didapat $\chi_{\text {tabel }}^{2}=12,59$. Karena harga $\chi_{\text {hitung }}^{2}$ $\leq \chi_{\text {tabel }}^{2}$ maka dapat disimpulkan bahwa hasil posstest kelas kontrol metode konvensional dinyatakan berdistribusi normal. Perhiungan uji normalitas dapat dilihat pada tabel di bawah ini:

Tabel 1

Rangkuman Hasil Uji Normalitas Penelitian

\begin{tabular}{lllr}
\hline Kelompok & $\boldsymbol{\chi}^{2}$ hitung & $\boldsymbol{\chi}^{2}$ tabel & Keterangan \\
\hline Eksperimen & 4,47 & & Normal \\
Kontrol & 4,07 & 12,59 & Normal \\
\hline
\end{tabular}

Setelah dilakukan uji normalitas terhadap hasil posstest kelas
maka selanjutnya dilakukan uji eksperimen dan kelas kontrol,masinghomogenitas. Berikut ini merupakan masing kelas tampak pada tabel hasil dari uji homogenitas varian berikut: terhadap hasil posttest siswa pada masing-masing kelas dengan menggunakan uji-F. Data hasil uji-F 
Tabel 2

Rangkuman Hasil Uji Homogenitas

\begin{tabular}{lllll}
\hline \multicolumn{1}{c}{ Kelas } & Varians & $\mathbf{F}_{\text {hitung }}$ & $\mathbf{F}_{\text {tabel }}$ & Keterangan \\
\hline Eksperimen & 70,56 & 1,278 & 2,15 & Homogen \\
Kontrol & 90,19 & & & \\
\hline
\end{tabular}

Hasil uji homogenitas dikatakan homogen dari data hasil uji-F terhadap hasil uji homogenitas posttest kelas eksperimen dan kelas kontrol dimana $\mathrm{F}_{\text {hitung }} \leq \mathrm{F}_{\text {tabel }}(1,278 \leq 2,15)$ maka hasil posttest yaitu varians homogen.

Setelah dilakukan uji normalitas dan homogenitas diketahui bahwa skor tes hasil belajar siswa pada kelompok berdistribusi normal dan memiliki varian yang homogen. Uji one tail test dilakukan terhadap rata-rata posttest kelas eksperimen dan kelas kontrol. Untuk mengetahui apakah ada peningkatan hasil belajar dari kelas eksperimen dan kelas kontrol statistik uji yang digunakan adalah dengan menggunakan uji one tail test.

\section{Uji Hipotesis 1}

Berdasarkan hasil penelitian dengan menggunakan model pembelajaran Resource Based Learning dapat meningkatkan hasil belajar matematika siswa.Terlihat dari deskripsi hasil data tentang hasil belajar siswa. Berdasarkan analisis data diketahui terdapat peningkatan skor hasil belajar matematika kelas yang menggunakan penerapan model pembelajaranResource

BasedLearning. Hal ini terlihat dari perhitungan dengan menggunakan uji one tail test terhadap nilai posttest kelas eksperimen diperoleh nilai $\quad t_{\text {hitung }}(7,87) \geq$ $t_{\text {tabel }}(1,721)$, dengan taraf nyata $\alpha$
$=0,05$. Karena $t_{\text {hitung }}(7,87) \geq$ $t_{\text {tabel }}(1,721)$, maka $\mathrm{H}_{01}$ ditolak dan $\mathrm{H}_{\mathrm{a} 1}$ diterima, jadi terdapat peningkatan pada pencapaian skor hasil belajar matematika siswa yang mendapat pembelajaran dengan menggunakan model pembelajaran Resource Based Learning. Berdasarkan data yang telah di uji normalitas dan homogenitasnya terlebih dahulu pada kelas eksperimen dan kelas kontrol data berdistribusi normal dan homogen. Sehingga dapat disimpulkan bahwa model pembelajaran Resource Based Learning efektif ditinjau dari hasil belajar matematika siswa kelas VIII MTs Al Muttqin.

2. Hipotesis 2

Selanjutnya berdasarkan analisis data diketahui terdapat peningkatan skor hasil belajar matematika kelas VIII yang menggunakan uji one tail test terhadap nilai posttest kelas kontrol diperoleh nilai $t_{\text {hitung }}=$ $1,53 \leq t_{\text {tabel }}=1,729$ dengan taraf nyata $\alpha=0,05$. Karena $t_{\text {hitung }}=$ $1,53 \leq t_{\text {tabel }}=1,729$ maka $H_{a 2}$ ditolak, ini berarti tidak terdapat pada pencapaian skor hasil belajar matematika siswa yang mendapat pembelajaran menggunakan metode konvensional. Sehingga dapat disimpulkan bahwa model 
pembelajaran konvensional tidak efektif ditinjau dari hasil belajar matematika siswa kelas VIII MTs Al Muttqin.

3. Uji hipotesis 3

Berdasarkan hasil dari $t_{\text {hitung }}=3,90 \geq t_{\text {tabel }}=1,684$ dengan taraf nyata $\alpha=0,05$. Disini dapat dilihat bahwa $t_{\text {hitung }}=$ $3,90 \geq t_{\text {tabel }}=1,684$ maka $H_{a 3}$ diterima $H_{03}$ ditolak, berarti terdapat perbedaan pada pencapaian skor hasil belajar siswa antara siswa yang mendapatkan pembelajaran dengan model pembelajaran Resource Based Learning dengan siswa yang mendapatkan pembelajaran dengan metode konvensional. Dari perhitungan separated varians pada kelas eksperimen dan kelas control diperoleh $t_{\text {hitung }}(3,90) \leq$ $t_{\text {tabel }}(1,68)$, dengan membandingkan nilai $t_{\text {hitung }} \geq t_{\text {tabel }}$ ini berarti $\mathrm{H}_{03}$ ditolak dan $\mathrm{H}_{a 3}$ diterima. Sehingga dapat disimpulkan bahwa terdapat perbedaan yang signifikan terhadap Model pembelajaran Resource Based Learning dengan pembelajaran konvensional ditinjau dari hasil belajar matematika siswa kelas VIII di MTs Al Muttaqin.

Pembelajaran

dengan

menggunakan model pembelajaran Resource Based Learning dapat meningkatkan hasil belajar matematika siswa dibandingkan pembelajaran dengan menggunakan metode konvensional. Proses pembelajaran dengan menggunakan pembelajaran Resource Based Learning menjadikan siswa menjadi lebih mampu berpartisipasi dalam pembelajaran, menjadi lebih aktif secara fisik, aktif dalam berkomunikasi dalam kelompok, menjadi lebih mengetahui inti dari pembelajaran yang mereka lakukan dengan adanya kesimpulan, mampu menyelesaikan masalah-masalah yang berkaitan dengan materi, serta kesan senang dalam pembelajaran lebih terlihat. Sedangkan pembelajaran dengan menggunakan metode konvensional menjadikan peran guru sangat dominan di dalam kelas, dan siswa menjadi kurang aktif, siswa hanya mengikuti kehendak guru baik apa yang ditulis maupun apa yang telah disampaikan guru, suasana kelas yang terkesan sunyi menjadi sangat dominan dalam kelas, meskipun dalam pelaksanaan pembelajaran siswa juga telah diberi waktu untuk aktif dalam bertanya, akan tetapi hasil pembelajaran tetaplah terkesan sunyi.

\section{SIMPULAN DAN SARAN}

Berdasarkan penelitian yang telah di laksanakan dapat di ambil kesimpulan bahwa Model pembelajaran Resource Based Learning efektif ditinjau dari hasil belajar matematika pada siswa kelas VIII di MTs Al Muttaqin Batam. Selain disimpulkan bahwa Model pembelajaran konvensional tidak efektif ditinjau dari hasil belajar matematika pada siswa kelas VIII di MTs Al Muttaqin Batam. Selanjutnya terdapat perbedaan yang signifikan terhadap model pembelajaran Resource 
Based Learning dengan pembelajaran konvensional ditinjau dari hasil belajar matematika pada siswa kelas VIII di MTs Al Muttaqin.

\section{DAFTAR PUSTAKA}

Aliyah, U. H., Suyitno, H., \& Agoestanto, A. (2014). Keefektifan Resource Based Learning terhadap Kemampuan Pemecahan Masalah Peserta Didik Materi Lingkaran. Jurnal Pendidikan Matematika dan Sains, 2(1), 10-18.

Arikunto, Suharsimi. (2012). Statistik Untuk Penelitian. Bandung: Alfabeta.

Bagindo, R., \& Yulia, P. (2019). Efektivitas Model Pembelajaran Aptitude Treatment Interaction (ATI) dengan Team Assisted Individualization (TAI) terhadap Hasil Belajar Siswa. Pythagoras: Jurnal Program Studi Pendidikan Matematika, 8(1).

Dewi, E. K., \& Yulia, P. (2018). Efektivitas Penerapan Model Pembelajaran TAI dan PBI terhadap Hasil Belajar Matematika Siswa Kelas VIII SMPN 50 Batam. Pythagoras: Jurnal Program Studi Pendidikan Matematika, 7(2).

Nasution. (2003). Berbagai Pendekatan Dalam Proses Belajar Mengajar. Jakarta. PT Bumi Aksara.

Pendidikan Nasional. 2003 Undangundang No. 20 tentang sistem pendidikan.

Siregar, Eveline. (2009). Pengembangan Belajar Berbasis Aneka Sumber, Diakses dari http://www.teknologipendidikan.n et/pengembangan-belajarberbasisaneka-sumber-resourcesbased-learning. Pada tanggal 4 September 2011.
Suharsimi. (2006). Prosedur Penelitian "Suatu Pendekatan Praktik".Jakarta. PT.Rineka.

Yulia, P. (2016). Pengembangan Perangkat Pembelajaran Berbasis Problem Based Learning (PBL) untuk Kelas V SD. In Seminar Nasional (Vol. 1, No. 1). 